\title{
Bison and Cattle Digestion of Forages from the Slave River Lowlands, Northwest Terri- tories, Canada
}

\author{
A.W.L. HAWLEY, D.G. PEDEN, H.W. REYNOLDS, AND W.R. STRICKLIN
}

\section{Abstract}

Dry matter disappearance (DMD) of native forages collected from the Slave River Lowlands (SRL), Northwest Territories, was consistently greater in bison (Bison bison) than in Hereford cattle (Bos taurus) when measured with a nylon bag technique. Overall average DMD values were $52 \%$ and $39 \%$ for bison and cattle, respectively. Mean percent DMD values for each plant species were: willow (Salix spp.), 56; slough sedge (Carex atherodes), 50; baltic rush (Juncus balticus), 47; aleppo avens (Geum aleppicum), 44; and northern reedgrass (Calamagrostis inexpansa), 39. Dry matter disappearance was inversely correlated $(P<0.05)$ with crude fiber content of the sample. Dependence of DMD on crude fiber content was less $(P<0.001)$ in cattle than in bison. Based on relative digestibilities and data on forage intake, we concluded that slough sedge was the most important bison forage in the study area. Average DMD was $44 \%$ greater $(P<0.01)$ in a Hereford fed hay than in a Hereford fed hay plus a concentrate supplement. There was no difference $(P>0.05)$ in DMD between two bison fed the hay ration and two fed hay plus the supplement.

The Slave River Lowlands (SRL) (approximately $60^{\circ}$ to $61^{\circ} \mathrm{N}$ latitude; $112^{\circ}$ to $113^{\circ} \mathrm{W}$ longitude) is the home range of approximately 400 wild bison. An assessment of this area as range for bison and cattle was undertaken because of its importance to bison and because of a growing interest in the potential of this area as cattle range (Reynolds ct al. 1978). Too few data are available for making empirical comparisons of digestibility between bison and cattle. Comparative data on the digestion of grass, sedge, and alfalfa hays of bison, yak, and cattle were reported by Richmond et al. (1977). Peden et al. (1974) comparcd the digestibilities of forages grazed by bison and cattle using a nylon bag technique. This technique has been useful for ranking the digestibilities of different feedstuffs (Figroid et al. 1972; Kercher et al. 1964), assessing the effect of different rations on digestibility (cl-Shazly et al. 1961; Neathery 1969) and comparing the digestive capacities of animal species (Peden et al. 1974; Van Dyne 1962). The objectives of the present experiment were (1) to compare the digestibilities of native forages from the SRL, (2) to compare the digestive capacities of bison and cattle, and (3) to compare the effects of feeding a roughage as opposed to a roughage and concentrate ration on these digestibilities. The nylon bag technique was therefore well suited to our needs

Authors are wild life biologist, Alberta Environmental Centre, Vegreville, Alberta research scientist, Canadian Wildlife Service, Saskatoon, Saskatchewan; biologist, Canadian Wildlife Service, Edmonton, Alberta, and assistant professor, Departmen of Animal Science, University of Maryland, College Park.

The authors gratefully acknowledge the assistance of R.M. Hansen, Range Science Department, E. Keith and R. Souther, Natural Resource Ecology Laboratory, Colorado State University, Fort Collins, and the statistical assistance of G.E.J. Smith, Canadian Wildlife Service, Ottawa, Ontario. We also thank R.H. Russell and M.C.S Kingsley, Canadian Wild life Service, Edmonton, Alberta, for their valuable reviews of this manuscript. Analyses of sample ether extract and crude fiber contents were conducted by the Department of Animal and Poultry Scicncc, University of Saskatchewan, Saskatoon, and the Alberta Soil and Feeding Testing Laboratory, Edmonton, respectively.

The study was supported by Canadian Wildlife Service Contract No. 0SZ5-0285. Manuscript received August 14, 1979. and was chosen to make these comparisons.

\section{Materials and Methods}

Samples of native forages were collected in the SRL in February and June, 1975. Summer samples of willow consisted of approximately equal dry weights of leaves and twigs from the terminal 12 $\mathrm{cm}$ of the twigs. Winter willow samples were comprised of twigs only. Herbaceous plant samples included the entire aerial portion of the plant cut at approximately $2 \mathrm{~cm}$ above ground. All samples were air-dried and ground through a 1-mm mesh screen.

Nylon bag digestibility experiments were conducted using two ruminally fistulated adult Hereford cattle and four ruminally fistulated adult bison at the Pawnee Site, International Biological Program, Nunn, Colorado, during January 1976. One Hereford and two bison were fed crested wheatgrass hay containing $6 \%$ crude protein (CP) (Table 1). One Hereford and two bison were fed

Table 1. Animals used in nylon bag digestibility experiments.

\begin{tabular}{llcl}
\hline \hline & & Body \\
Seight & \\
Species & Sex & $(\mathrm{kg})$ & Ration \\
\hline Cattle & Male & 598 & hay \\
& Female & 494 & hay plus supplement \\
Bison & Female & 449 & hay \\
& Female & 450 & hay \\
& Male & 497 & hay plus supplement \\
& Female & 455 & hay plus supplement \\
\hline
\end{tabular}

crested wheatgrass hay plus a pelleted $15 \%$ CP supplement (Table 2 ). Both the hay and supplement were fed ad libitum. Feed consumption was recorded on a herd basis. Three bison ( 2 of which were used in the study) and 1 Hereford receiving only hay con-

Table 2. Composition of a ration supplement fed to bison and cattle during nylon bag digestibility experiments'.

\begin{tabular}{lr} 
Component & $\%$ \\
\hline Pulverized barley & 9.92 \\
Pulverized corn & 29.97 \\
Pulverized milo & 4.96 \\
Pulverized oats & 7.44 \\
Wheat midland (mill feed) & 6.45 \\
Shredded beet pulp & 2.48 \\
Brewer's dried grain & 34.74 \\
Di-calcium phosphate & .99 \\
Vitamin pre-mix & .02 \\
(Vitamins A and D; 55,000 units/kg) & .05 \\
Trace minerals & 2.48 \\
Molasses & 99.50 \\
Total &
\end{tabular}

'From Keith (1977). 
sumed an average of $7.4 \mathrm{~kg}$ of hay per animal per day. Three bison ( 2 of which were used in the study) and 1 Hereford receiving hay plus the grain supplement consumed an average of 3.7 and $3.8 \mathrm{~kg}$ per animal per day of hay and supplement, respectively. The $C P$ content of the ration consumed by animals receiving the supplement was calculated to be $10.6 \%$.

Two digestibility trials were conducted using bags made of parachutc nylon cloth. In the first trial, all animals were tested. In the second trial, one Hereford and one bison were tested on each ration. The bags were $9.5 \mathrm{~cm}$ long and $12.0 \mathrm{~cm}$ in circumference. The pore size of the material was approximately $15 \times 23 \mu$. Less than $1 \%$ of the initial sample dry matter (DM) was lost from the bags prior to intraruminal incubation. In each of two trials, $2 \mathrm{~g}$ subsamples of each forage were placed into dried and weighed nylon bags which were then tied securely with a nylon drawstring, oven-dried at $68^{\circ} \mathrm{C}$ for 48 hours, cooled to room temperature in a dessicator, and weighed to the nearest $10 \mathrm{mg}$.

The nylon bags containing forage were fastened along a nylon line, approximately $1.5 \mathrm{~cm}$ apart. The total distance occupied by the bags along the line was approximately $39 \mathrm{~cm}$. One end of the line was weighted, the line was inserted into the rumen of an animal, and the unweighted end of the line was attached to the rumen cannula leaving at least $32 \mathrm{~cm}$ of line between the most proximal bag and the cannula. Forage samples were always inserted and removed in the early afternoon. There were 2 or 3 bags of each forage on each line for each incubation. After $48 \mathrm{~h}$ digestion, the bags were removed from the rumen, group-rinsed by hand until extruded water was clear, oven-dried for $48 \mathrm{~h}$, and residual DM was determined. Dry matter disappearance (DMD) was used as a measure of digestibility. Dry matter disappearance values for individual samples were mathematically corrected for the effect on DMD of the location of the bags on the string (Hawley 1981).

The variability among replicate bags within a single rumen was small and the values were averaged to give one digestion value per forage for each incubation. These averaged values were analyzed using analysis of variance with animals and trials as replicates (Kim and Kohout 1975). Significance of differences among different levels of a single variable were tested using Student-NewmanKeul's multiple range test (Steel and Torrie 1960). Dry matter disappearance appeared to be inversely and logarithmically related to the crude fiber (CF) content of the sample. The relationship between DMD and CF content was therefore analyzed by linear regression of log-transformed data (Nie et al. 1975) with animals and trials as replicates for each plant species in each season. Regression coefficients were compared as outlined by Stanley (1963). The degree to which the transformed DMD was linearly dependent on the transformed CF content was compared between regressions using a ratio of error mean squares (EMS).

\section{Results}

\section{Dry Matter Disappearance}

The analysis of variance of DMD values revealed that all main effects and several intcractions were significant (Table 3).

All forages had greater DMD values in bison than in cattle (Tables 4 and 6). Dry matter disappearance did not differ significantly between rations for bison but was significantly lower for cattle receiving the grain supplement than for cattle receiving hay alone.

Willow had the highest overall mean DMD and northern reedgrass the lowest (Table 5). The difference in digestibility between summer and winter samples was large for aleppo avens and northern reedgrass, intermediate for sedge and baltic rush, and low for willow.

The greatest differences in digestibilities among various forages occurred among winter samples (Table 6). Differences among forage DMD values were greater in cattle than in bison. In bison, slough sedge, willow, and baltic rush had the greatest average DMD (Table 6). In cattle, the average DMD of willow was significantly greater than that of all other forages and alcppo avens had a
Table 3. Analysis of variance of dry matter disappearance of five native forages harvested in summer and winter and tested in bison and cattle fed hay or hay plus supplement.

\begin{tabular}{lcc}
\hline \hline Source of variation 1 & df & Mean square \\
\hline Animal species & 1 & $4480^{* * * 2}$ \\
Diet & 1 & $859^{* * *}$ \\
Season & 1 & $13180^{* * *}$ \\
Plant species & 4 & $756 * * *$ \\
Animal species $X$ diet & 1 & $100^{* * *}$ \\
Animal species $X$ season & 1 & 0 \\
Animal species $X$ plant species & 4 & $421 * * *$ \\
Diet $X$ season & 1 & 11 \\
Diet $X$ plant species & 4 & $82 * *$ \\
Season $X$ plant species & 4 & $1108^{* * *}$ \\
Residual & 77 & 21 \\
\hline
\end{tabular}

13-way and higher order interactions were not significant $(P>0.05)$ and their sums of squares were pooled with the residual. $2 * * P<0.01 ;{ }^{* * *} P<0.001$.

greater DMD than the remaining forages.

The diet $X$ plant interaction was significant (Table 3 ) but involved only the reversal of the ranking of DMD values for the plant species with the two lowest DMD values, namely northern reedgrass and aleppo avens. The ranking of the DMD values of the other plant species was unaffected by diet.

Winter samples had markedly greater CF contents than summer samples in all species except willow (Table 7). The percentage reduction in DMD in winter versus summer samples (Table 5) was highly correlated $(r=0.90)$ with the percentage increase in CF content of winter samples (Table 7).

\section{Relationship Between DMD and Sample CF Content}

Expressing the $\log$ of DMD as a function of the $\log$ of $C F$ content of the respective sample resulted in a negative linear regression in each of the four a nimal-diet combinations (Fig. 1). Data for willow were excluded from these regressions since the willow samples had DMD values which were so high as to not appear to fit the relationships between CF and DMD displayed by other forages. All correlation coefficients were significant $(P<0.05)$. The ratios of EMS indicated that the linear dependency of the log of DMD on the $\log$ of $C F$ content was significantly greater $(P<0.001)$ in bison receiving either ration than in cattle receiving either ration. In addition, this dependency was not affected by diet in bison, but was significantly lower $(P<0.001)$ for cattle receiving the supplement than for cattle receiving hay alone. The relationships of EMS were unchanged when between and within animal variabilities were removed from all regressions. There were no significant differences $(P>0.05)$ among the four regression coefficients.

\section{Discussion}

\section{Comparison of Forage Digestibilities}

Slough sedge was observed to be the most digestible herbage tested overall. It predominates in the diets of bison in the SRL and,

Table 4. Means, standard errors (SE), and number of observations (n) of nylon bag dry matter disappearance (DMD) of plant samples tested in bison and cattle receiving different rations.

\begin{tabular}{|c|c|c|c|}
\hline \multirow[b]{3}{*}{ Ration } & \multicolumn{3}{|c|}{ DMD $(\%)$} \\
\hline & Bison & Cattle & Average \\
\hline & Mean $\pm S E n$ & Mean $\pm S E n$ & Mean $\pm \mathrm{SE}$ \\
\hline $\begin{array}{l}\text { Hay } \\
\text { Hay plus }\end{array}$ & $53 \mathrm{a}^{1} \pm 2.830$ & $46 \mathrm{a} \pm 3.520$ & $50 \mathrm{a} \pm 2.2$ \\
\hline $\begin{array}{l}\text { supplement } \\
\text { Average }^{2}\end{array}$ & $\begin{array}{l}52 \mathrm{a} \pm 2.830 \\
52 \pm 2.0\end{array}$ & $\begin{array}{l}32 b \pm 4.020 \\
39 \pm 2.9\end{array}$ & $44 b \pm 2.7$ \\
\hline
\end{tabular}

WWithin columns, means followed by different letters were significantly different $(P<0.01)$.

${ }^{2}$ Animal species averages were significantly different $(P<0.001)$. 
Table 5. Means and standard errors (SE) of nylon bag dry matter disappearance (DMD) of five plant species collected in two seasons.

\begin{tabular}{|c|c|c|c|c|c|}
\hline \multirow[b]{3}{*}{ Plant species } & & \multicolumn{2}{|c|}{ DMD $(\%)$} & \multirow{3}{*}{$\begin{array}{c}\text { Seasonal } \\
\text { reduction }\left(\%^{2}\right)\end{array}$} & \multirow{2}{*}{$\frac{\text { DMD (\%) }}{\text { Average }}$} \\
\hline & & Summer & Winter & & \\
\hline & & Mean $\pm \mathrm{SE}^{1}$ & Mean $\pm \mathrm{SE}^{1}$ & & Mean $\pm \mathrm{SE}$ \\
\hline Carex atherodes & & $60 b^{3} \pm 4.1$ & $40 \mathrm{~b} \pm 4.9$ & 33 & $50 \mathrm{~b} \pm 3.9$ \\
\hline Salix spp. & & $59 b \pm 1.2$ & $52 \mathrm{a} \pm 1.2$ & 11 & $56 \mathrm{a} \pm 1.1$ \\
\hline Calamagrostis inexpansa & & $57 b \pm 4.3$ & $22 c \pm 2.9$ & 62 & $39 \mathrm{e} \pm 4.7$ \\
\hline Juncus balticus & & $52 \mathrm{c} \pm 4.7$ & $39 b \pm 4.3$ & 24 & $47 c \pm 3.4$ \\
\hline Geum aleppicum & - & $65 \mathrm{a} \pm 1.0$ & $24 c \pm 0.5$ & 64 & $44 \mathrm{~d} \pm 4.8$ \\
\hline Average & & $\pm 1.6^{4}$ & $35 \pm 2.1$ & & \\
\hline
\end{tabular}

${ }^{\prime} n=10$

2The seasonal reduction in DMD was determined by expressing the difference between summer and winter means as a percentage of the summer mean.

${ }^{3}$ Within columns, means followed by different letters were significantly different $(P<0.05)$.

${ }^{4}$ Seasonal averages were significantly different $(P<0.001)$.

together with reedgrasses, constitutes at least $70 \%$ of the diet (Reynolds et al. 1978). A preference for feeding on sedge has also been observed in bison in Yellowstone National Park (Meagher 1973) and in bison bulls in Elk Island National Park (Holsworth

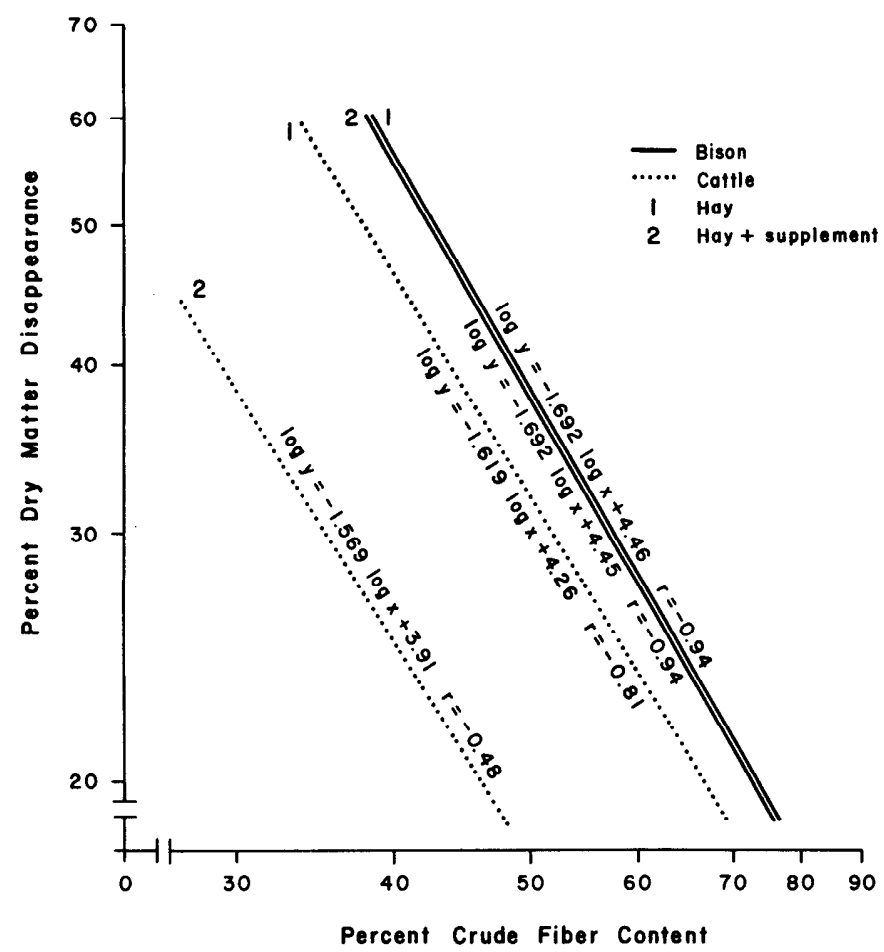

Fig. 1. Linear regressions of the log of percent dry matter disappearance as a function of the log of plant sample percent crude fiber content for bison and cattle receiving hay or hay plus supplement. For each bison and cattle regression $n=24$ and $n=16$, respectively.
1960). Since it both predominates in the diet and is highly digestible, slough sedge is energetically the most important native forage for free-ranging bison in the SRL. This forage would also be an important native forage for cattle introduced into the SRL because it is the second most abundant herbage in meadow habitats of the SRL (Reynolds et al. 1978). In cattle, summer sedge samples were more digestible than summer reedgrass samples.

The DMD of willow was relatively high, especially among winter samples. The observation that willow DMD was greater than would be expected contrasts with the findings of Short et al. (1974), who found that mature southern browses (willow not included)

Table 7. Ether extract and crude fiber contents (\% of dry matter) of five plant species collected in summer and winter.

\begin{tabular}{|c|c|c|c|c|c|}
\hline \multirow[b]{3}{*}{ Plant species } & \multirow{2}{*}{\multicolumn{2}{|c|}{$\begin{array}{c}\text { Ether extract } \\
\text { Season } \\
\end{array}$}} & \multicolumn{3}{|c|}{ Crude fiber. } \\
\hline & & & \multicolumn{2}{|c|}{ Season } & \multirow{2}{*}{$\begin{array}{r}\text { Seasonal } \\
\text { increase } \%\end{array}$} \\
\hline & Summer & Winter & Summer & - Winter & \\
\hline Carex atherodes & 0.8 & 0.9 & 36.4 & 43.7 & 20 \\
\hline Salix spp. & 3.6 & 5.3 & 47.6 & 47.1 & -1 \\
\hline Calamagrostis inexpansa & 0.6 & 0.1 & 37.7 & 52.4 & 39 \\
\hline Juncus balticus & 1.7 & 0.9 & 36.9 & 41.1 & 12 \\
\hline Geum aleppicum & 1.1 & 0.8 & 38.4 & 70.1 & 83 \\
\hline
\end{tabular}

'The seasonal increase in $\mathrm{CF}$ content was determined by expressing the difference between summer and winter means as a percentage of the summer mean.

displayed DMD values lower than would be expected based on the relationship between cell wall content and DMD of the herbages. Although they found mature browse had a lower maximum digestibility than mature grasses, browse attained near maximum digestibility at a greater rate. Over incubation times of approximately 18 $\mathrm{h}$ or less, mature browse exceeded mature grasses in digestibility. The incubation period of $48 \mathrm{~h}$ used in our experiment appears to have been long enough not to have imparted a relatively high DMD to willow due to a relatively rapid early digestion. All forage samples tested in our experiment were ground to pass through a

Table 6. Means and standard errors (SE) of nylon bag dry matter disappearance (DMD) of summer and winter samples of five plant species tested in bison and cattle.

\begin{tabular}{|c|c|c|c|c|c|c|}
\hline \multirow[b]{3}{*}{ Plant species } & \multicolumn{3}{|l|}{ Bison DMD $(\%)$} & \multicolumn{3}{|l|}{ Cattle DMD (\%) } \\
\hline & Summer & Winter & Average & Summer & Winter & Average \\
\hline & $\overline{\text { Mean } \pm \mathrm{SE}^{1}}$ & Mean $\pm \mathrm{SE}^{1}$ & Mean \pm SE & $\overline{\text { Mean } \pm \mathrm{SE}^{2}}$ & $\overline{\text { Mean } \pm \mathrm{SE}^{2}}$ & Mean $\pm \mathrm{SE}$ \\
\hline Carex atherodes & $67 \mathrm{a}^{3} \pm 2.0$ & $50 \mathrm{ab} \pm 1.8$ & $59 \mathrm{a} \pm 3.0$ & $48 c \pm 6.6$ & $26 b \pm 7.6$ & $37 c \pm 6.3$ \\
\hline Salix spp. & $61 \mathrm{a} \pm 0.9$ & $55 \mathrm{a} \pm 0.7$ & $58 \mathrm{a} \pm 1.1$ & $55 \mathrm{~b} \pm 1.8$ & $49 \mathrm{a} \pm 2.0$ & $52 \mathrm{a} \pm 1.7$ \\
\hline Calamagrostis inexpansa & $65 \mathrm{a} \pm 1.9$ & $28 c \pm 1.1$ & $46 b \pm 5.7$ & $45 c \pm 7.3$ & $13 c \pm 4.1$ & $24 \mathrm{~d} \pm 7.2$ \\
\hline Juncus balticus & $61 \mathrm{a} \pm 2.4$ & $48 b \pm 1.4$ & $55 \mathrm{a} \pm 2.3$ & $38 \mathrm{~d} \pm 7.2$ & $26 b \pm 5.9$ & $32 \mathrm{~d} \pm 4.9$ \\
\hline Geum aleppicum & $66 \mathrm{a} \pm 1.3$ & $24 c \pm 0.4$ & $45 b \pm 6.3$ & $63 \mathrm{a} \pm 1.3$ & $23 b \pm 0.9$ & $43 b \pm 7.8$ \\
\hline
\end{tabular}

${ }^{1} n=6$.

$2 n=4$.

${ }^{3}$ Within columns, means followed by different letters were significantly different

$(P<0.05)$. 
1-mm mesh screen, whereas Short et al. (1974) used ground particles which would not pass through a $2-\mathrm{mm}$ screen. Finer grinding may have produced greater physical destruction of fiber, thereby preferentially enhancing DMD of willow samples in our experiment.

Willow samples were comparable to the portion of the plant browsed by free-ranging bison. Herbage samples were derived from the entire aerial part of the plants and were, therefore, comparable to harvested hay and not to the portion of the plant usually grazed by free-ranging bison. Had herbage samples been derived solely from the leafy portions of the plants, the difference between herbage and willow DMD might have been reduced. Nevertheless, the high DMD of willow samples suggests that willow is potentially important as a source of energy for ruminants in the SRL in the winter. Bison evidently do not utilize this energy source to a large extent since the maximum content of willow in winter bison diets in the SRL as estimated by fecal analysis was $2 \%$ (Reynolds 1976). Slough sedge and reedgrass made up 30 and $32 \%$ respectively, of these diets. The differences in DMD between willow and the other forages tested were not great enough to attribute the low proportion of willow in winter fecal samples to differential digestibilities. Using DMD values for winter samples tested in bison (Table 6) and ether extract values of winter samples (Table 7), willow would contribute only $4 \%$ of the total digestible energy that would be provided by the forages tested. Therefore, willow would not appear to be a major energy source for bison in the winter. If snow depth or ice conditions forced the bison to browse extensively, willow might then be an important energy source for bison.

\section{Comparison of Bison and Cattle Rumen Function}

In all instances, forage digestion was greater in bison than in cattle. This is in agreement with other studies in which the digestion of low protein, high fiber forage was observed to be greater in bison than in cattle (Peden et al. 1974; Richmond et al. 1977). Peden et al. (1974) suggested that differences in the recycling of urea could explain the greater digestion of low protein rations in bison. If this hypothesis is correct, then the differences in digestion between bison and cattle should be greatest when nitrogen in the diet is limited. Peden et al. (1974) observed that bison displayed greater digestibilities than cattle only when rations contained less than $7 \%$ CP. Perhaps CP concentrations less than approximatcly $7 \%$ depressed rumen cellulolysis. It appears that $5 \% \mathrm{CP}$ is required to maintain cellulose digestion (Gilchrist and Clark 1957). Fiber digestion is reduced in sheep when rations contain less than 5 to $6 \%$ CP (Glover and Dougall 1960; Moir and Harris 1962).

In our experiment, forage digestibility coefficients for animals receiving the hay ration were significantly greater in bison than in cattle. The CP content of the hay was low $(6 \%)$, and thus the greater digestion of forages by bison agrees with the observations of Peden et al. (1974). However, DMD was also greater in bison than in cattle when ration CP was increased by feeding the ration supplement. This supplement supplied both protein and soluble carbohydrate. The addition of soluble carbohydrates to feeds usually depresses the digestion of fibrous materials in domestic ruminants (Church 1975; el-Shazly et al. 1961). In our experiment, forage DMD in cattle was lower with the supplemented ration. Although CP was also supplemented, the effect of the ration supplement on forage digestion was primarily that of a soluble carbohydrate supplement.

El-Shazly et al. (1961) suggested that the ratio of available energy to available nitrogen is important in explaining the decrease in cellulolytic activity induced by an increase in the level of soluble carbohydrates. Increased soluble carbohydrate results in increased available energy and increased competition for nitrogen, but with a metabolic advantage imparted to amylolytic versus cellulolytic bacteria. This results in a net decrease in cellulolytic activity.

Intraruminally, the presence of starch and other soluble polysaccharides reduces the amount of free nitrogen by increasing nitrogen utilization (Church 1975). Slyter et al. (1971a) observed that the addition of starch to high fiber purified diets fed to beef steers increased nitrogen retention and decreased excretion of urinary nitrogen. Starch supplements increased the total number of ruminal bacteria but decreased fiber digestion and the number of cellulolytic bacteria in steers (Slyter et al. 1971a, 1971b) and sheep (Gilchrist and Clark 1957). This was attributed to the inability of the cellulose digesting microbes to compete with the much more rapidly growing users of starch, sugar, and lactic acid for the limited supply of nitrogen. El-Shazly et al. (1961) demonstrated a marked reduction in cellulose digestion in vitro when starch or glucose were added to the fermentation flask, and in situ in the rumen when ground shelled corn was added to a hay ration. The reduction in cellulose digestion was proportional to the amount of corn added. The addition of urea to a diet consisting of equal weights of hay and corn reversed the inhibition of cellulolysis, and the reversal increased with greater amounts of urea added (elShazly et al. 1961). The depression of cellulolysis and the reversal of this effect were evident despite a CP content of $11.9 \%$ in the ration consisting of equal weights of hay and corn. In our study, the availability of nitrogen in the rumen may have been limiting with the ration supplement despite a CP content over $10 \%$ because of the high availability of soluble carbohydrate.

Individual animal differences may have contributed inordinately to the large differences in DMD between cattle receiving different rations since only one Hereford was tested with each ration. However, individual animal differences in DM digestibility rarely exceed 5\% (Paquay et al. 1972) while we observed a difference between cattle in overall DMD of $44 \%$ (Table 4). Since the hay and grain were fed ad libitum, bison receiving the ration supplement may have consumed relatively less grain than the Hereford receiving the ration. However, Peters (1958) observed that the proportions of hay and grain consumed were similar in bison and cattle. The type of ration had no significant effect on DMD in bison even though bison consumed large quantities of the supplement.

The highly significant animal $\times$ diet interaction can be explained by the postulated difference in nitrogen recycling. Based on this hypothesis, cattle were less able to digest the forages when receiving the ration supplement because the primarily amylolytic microbes outcompeted the primarily cellulolytic microbes for nitrogen. Cellulolysis was less impaired in bison because of their greater capacity to recycle nitrogen to their rumens. Greater nitrogen recycling would reduce the energy:nitrogen ratio in bison relative to cattle, reduce competition for nitrogen, and reduce the depression of cellulolysis. Thus, the results of this study can be explained by postulating a greater capacity of bison to recycle nitrogen. This ignores possible species differences in the supply of other nutrients or in rumen buffering, which could also affect digestibility.

The greater cellulose digestion and lower sensitivity of cellulolysis to carbohydrate supplementation in bison compared to cattle are similar to the differences between water buffalo and Zebu cattle. Ichhponani et al. (1969) observed greater in vitro cellulose digestion with inoculum from buffalo than from Zebu cattle with all combinations of molasses, starch, and urea added to the incubation flasks. In addition, the depression of cellulolysis accompanying molasses or starch supplementation was more pronounced with inoculum from Zebu cattle than with that from buffalo. Because the animals received identical rations, these results can only be explained by hypothesizing differences between species in the composition of rumen liquor caused by an animal-induced mechanism.

Dry matter disappearance was inversely proportional to the $\mathrm{CF}$ content of the forage. The similarity a mong regression coefficients (Fig. 1) indicates that the relationships between forage CF and DMD were basically the same among the four regressions. Short et al. (1973) and Neathery (1969) observed negative linear correlations between DMD and the fiber content of the sample. Our results indicated that DMD was less dependent on forage CF in cattle than in bison and, therefore, was more dependent on other factors. This was also the case for the supplemented ration versus 
the hay ration, but only in cattle. These differences in correlation were not attributable to differences in animal and trial variabilities since the differences in correlations were unaffected when these sources of variation were removed. Interpreted on the basis of the differential nitrogen recycling hypothesis, these data suggest that increased competition for nitrogen (i.e. cattle versus bison; the supplemented ration versus the hay ration in cattle) resulted in microbial factors per se, namely competition for nitrogen, having a greater effect on DMD. Forage factors, namely CF content, had less of a determining effect and the dependence of DMD on CF content was reduced. Our results do not contradict the differential nitrogen recycling hypothesis.

In cattle, the dependence of DMD on CF content was greatest for the ration with the lowest CP content. Neathery (1969) also found that the correlation between DMD and sample $\mathrm{CF}$ was greater when a steer received a low $(7.4 \%)$ versus a high $(18.8 \%) \mathrm{CP}$ ration. These observations appear to conflict with the hypothesis that the correlation between DMD and CF is greatest when CP is not limiting. This conflict is explained by suggesting that the energy:nitrogen ratio, and not the level of nitrogen per se, is important in determining the effect of the competition for nitrogen on fiber digestion. In our study, although the CP level of the supplemented ration $(10.6 \%)$ was greater than that of the hay alone $(6 \%)$, nitrogen availability may have been more limiting to cellulolytic metabolism with the supplemented ration because of the high availability of soluble carbohydrates.

\section{Literature Cited}

Church, D.C. 1975. Digestive physiology and nutrition of ruminants Vol. 1. Digestive physiology. D.C. Church, Corvallis, Oregon. 350 p.

el-Shazly, K., B.A. Dehority, and R.R. Johnson. 1961. Effect of starch on the digestion of cellulose in vitro and in vivo by rumen micro-organisms. J. Anim. Sci. 20:268-273.

Figroid, W., W.H. Hale, and B. Theurer. 1972. An evaluation of the nylon bag technique for estimating rumen utilization of grains. J. Anim. Sci. 35:113-120.

Gilchrist, F.M.C., and R. Clark. 1957. Refresher courses in physiology. III. The microbiology of the rumen. J.S. Afr. Vet. Med. Ass. 28:295-309.

Glover, J., and H.W. Dougall. 1960. The apparent digestibility of the non-nitrogenous components of ruminant feeds. J. Agr. Sci., Camb. 55:391-394.

Hawley, A.W.L. 1981. The effect of bag location along a suspension line on nylon bag digestibility estimates in bison and cattle. J. Range Manage. (In press.)

Holsworth, W.N. 1960. Interactions between moose, elk and buffalo in Elk Island National Park, Alberta. M.Sc. Thesis. Univ. British Columbia, Vancouver. $92 \mathrm{p}$.

Ichhponani, J.S., G.S. Makkar, and G.S. Sidhu. 1969. Biochemical processes in the rumen. III. Effect of different carbohydrates on in vitro digestion of cellulose and utilization of urea nitrogen by rumen microorganisms from zebu and buffalo. Ind. J. Anim. Sci. 39:27-32.

Keith, E.O. 1977. Urea metabolism of North American bison. M.Sc. Thesis. Colorado State Univ., Fort Collins. 73 p.

Kercher, C.J., D.D. Gallinger, and H.D. Eikenberry. 1964. Nylon bag technique for measuring forage value. J. Anim. Sci. 23: 880 (Abstr.).

Kim, J-O., and F.J. Kohout. 1975. Analysis of variance and covariance: subprograms ANOVA and ONEWAY. p. 398-433 In: N.H. Nie, C.H. Hull, J.G. Jenkins, K. Steinbrenner and D.H. Bent, ed. SPSS. Statistical Package for Social Sciences. McGraw-Hill Book Co., Toronto. 675 p.

Meagher, M.M. 1973. The bison of Yellowstone National Park. Natl. Park Serv. Sci. Monogr. Scr. No. 1161 p.

Moir, K.J., and L.E. Harris. 1962. Ruminal flora studies in the sheep. X. Influence of nitrogen intake upon ruminal function. J. Nutr. 77:285-298.

Neathery, M.W. 1969. Dry matter disappearance of roughages in nylon bags suspended in the rumen. J. Dairy Sci. 52: 74-78.

Nie, N.H., C.H. Hull, J.G. Jenkins, K. Steinbbrenner, and D.H. Bent, ed 1975. Statistical Package for the Social Sciences. McGraw-Hill Book Co., New York. p. 276-300.

Paquay, R., R. De Baere, and A. Lousse. 1972. Statistical research on the digestibility in the cow. I. Dry matter and energy. J. Agr. Sci., Camb. 78: 135-139.

Peden, D.G., G.M. Van Dyne, R.W. Rice, and R.M. Hansen. 1974. The trophic ecology of Bison bison L. on shortgrass plains. J. Appl. Ecol. II. 489-498.

Peters, H.F. 1958. A feedlot study of bison, cattalo and Hereford calves. Can. J. Anim. Sci. 38:87-90.

Reynolds, H.W. 1976. Bison diets of Slave River Lowlands. Canada. M. Sc. Thesis. Colorado State Univ., Fort Collins. 66 p.

Reynolds, H.W., R.M. Hansen, and D.G. Peden. 1978. Diets of the Slave River lowland bison herd, Northwest Territories, Canada. J. Wildl. Manage. 42:581-590.

Richmond, R.J., R.J. Hudson, and R.J. Christophersen. 1977. Comparison of forage intake and digestibility of American bison, yak and cattle. Acta Therio. 22:225-230.

Short, H.L., R.M. Blair, and E.A. Epps, Jr. 1973. Estimated digestibility of some southern browse tissues. J. Anim. Sci. 36:792-796.

Short, H.L., R.M. Blair, and C.A. Segelquist. 1974. Fiber composition and forage digestibility by small ruminants. J. Wildl. Manage. 38:197-209.

Slyter, L.L., R.R. Oltjen, E.E. Williams, Jr. and R.L. Wilson. 1971a. Influence of urea, biuret and starch on amino acid patterns in ruminal bacteria and blood plasma and on nitrogen balance of steers fed high fiber purified diets. J. Nutr. 101:839-846.

Slyter, L.L., D.L. Kern, J.M. Weaver, R.R. Oltjen, and R.L. Wilson. 1971b. Influence of starch and nitrogen sources on ruminal microorganisms of steers fed high fiber purified diets. J. Nutr. 101: 847-854.

Stanley, J. 1963. The Essence of Biometry. McGill Univ. Press, Montreal. $147 \mathrm{p}$.

Steel, R.G.D., and J.H. Torrie. 1960. Principles and Procedures of Statistics. McGraw-Hill Book Co., New York. 481 p.

Van Dyne, G.M. 1962. Micro-methods for nutritive evaluation of range forages. J. Range Manage. 15:303-314

Soil Conservation and Range Management Specialists for upcoming overseas technical assistance projects in Subsaharan Africa. Experienced in Planning Implementation - Training - Evaluation of range management programs, including familiarity of on-farm cropping and soil conservation practices for semi-arid and arid areas. Overseas experience and foreign language capability desirable. Excellent benefits. Salary open. Please send resume responses to: J. Fiester/Recruitment, Chemonics International Consulting Division, 1120 - 19th Street, N.W., Suite 605, Washington, D.C. 20036. 